\title{
Teenage Technological Addictions (TTA) - Impact On Social Skills
}

\author{
P. Ramakrishna ${ }^{1}$, T. Rajini ${ }^{2 *}$
}

\section{ABSTRACT}

Technology creation "INTERNET" is rapid and becoming a natural background aspect of everyone in their daily life. It is considered as a double edged weapon both giving information and even giving side effects as well which are mostly ignored. Is widely used in terms of information seeking, communication, following telegraph, telephone, radio, and television. Postal a forgotten concept after the emergence of Internet. It acts as a bridge reaching mass audience. Research has not formally identified addictive use of the Internet as a problematic behavior. This study is focusing on the impact of social skills of the individuals with internet usage. Methods: Demographic Data Sheet, Internet Addiction Test, Social Skills Test \& Diagnostic Questionnaire. Data was analyzed. Conclusions: This study explores the continued prolonged usage of Internet and becoming addicted causing to the extent of impending misuse. Clinical and social inference of pathological Internet use and the future directions for research are discussed.

Keywords: Teenage Technological Addiction (TTA), Internet Addiction, Social Skills.

Technology is changing the nature of problems (Young, 1996). Symptoms often identified were a preoccupation with the internet, an inability to control use, hiding or lying about the behavior, psychological withdrawal, and continued use despite consequences of the behavior (Young, 2007).

Internet has positive aspects like informative, convenient, resourceful and fun, but for the excessive internet users, these benefits turn out to be useless and might misuse the same aspects. Very few suffer from the negative consequences of the internet usage but who are those is the research question in this study.

\footnotetext{
${ }^{1}$ Prof \& HOD, Psychiatrist, Deccan College of Medical Sciences, Hyderabad, India

${ }^{2}$ Clinical Psychologist, Deccan College of Medical Sciences, Hyderabad, India

*Responding Author

(C) 2016 I P Ramakrishna, T Rajini; licensee IJIP. This is an Open Access Research distributed under the terms of the Creative Commons Attribution License (http://creativecommons.org/licenses/by/2.0), which permits unrestricted use, distribution, and reproduction in any Medium, provided the original work is properly cited.
} 
People use the Internet for interpersonal activities (e.g., chat rooms, interactive gaming, and instant messaging) and to go online to meet people, form relationships, and seek emotional support

Internet is used to get in touch with other people accessibility, availability, intimacy, high stimulation and anonymity.

Marriages, dating relationships, parent-child relationships, and close friendships were also noted to be poorly disrupted by excessive use of the Internet. Dependents gradually spent less time with real people in their lives in exchange for solitary time in front of a computer.

Healthy usage of internet use is indicative of reasonable amount of time spent without cognitive or behavioral discomfort.

Loved ones first rationalize the obsessed Internet user's behavior as "a phase" in hopes that the attraction would soon dissipate. However, when addictive behavior continued, arguments about the increased volume of time and energy spent on-line soon ensue, but such complaints were often deflected as part of the denial exhibited by Dependents.

They become angry and resentful at others who questioned or tried to take away their time from using the Internet, often times in defense of their Internet use to a husband or wife. Engaged in the same lying about how long their Internet sessions really lasted or they hide bills related to fees for Internet service. These behaviors created distrust that over time hurt the quality of once stable relationships.

Spouses are replaced with rendezvous with electronic lovers, leaving no quality time for their marriages.

Marriages and dating relationships were mostly disrupted as finding new relationships with online friends as they are viewed as exciting and lead to romantic interactions gradually to Cybersex (i.e., on-line sexual fantasy role-playing). Cybersex and romantic conversations were perceived as harmless interactions as these sexual on-line affairs did not involve touching and electronic lovers lived thousands of miles away.

Financial problems were reported among Dependents who paid for their on-line service. Workrelated problems when they used their employee on-line access for personal use.

Psychologists and educators are aware of the potential negative impact from excessive use and related physical and psychological problems (Griffiths \& Greenfield, 2000). 
Individuals spending more amount of time online often experience academic, relationship, financial, and occupational difficulties, as well as physical impairments (Chou, 2001).

Some researchers (Brenner, 1997; Nie \& Erbring, 2000) have even linked internet use with an increase in psychological difficulties such as depression and loneliness.

Problematic internet use can cause internet addiction. (Young, 1996) characterized internet addiction as staying online for pleasure averaging 38 hours or more per week, largely in chat rooms, and concluded that internet addiction can shatter families, relationships, and careers.

Young further categorized five specific types of internet addiction: (1) Cyber sexual addiction to adult chat rooms or cyber porn;(2) Cyber relationship addiction to online friendships or affairs that replace real-life situations; (3) Net compulsions to online gambling, auctions, or obsessive trading; (4) Information overload to compulsive web surfing or databases searches; and (5) Computer addiction to game playing or programming (Young, 1998).

Problematic internet use is a psychiatric condition which involves maladaptive thoughts and pathological behavior" (Davis, 2002).

Internet connection and discovered through devices and found that only 23\% usage was business-related (Neuborne, 1997).

Problematic internet use is excessive time spent on various activities on the internet to an extent that might have negative effects on the user's physical and

Psychological health; social, academic, professional, and marital relationships, and other areas of life (Young, 1997).

Morahan-Martin and Schumacher (2000) define problematic internet use as intensive use of the internet, failure to control internet use, serious harm to the user's life resulting from this use. Problematic internet use has been associated with increases in impulsivity and increases in social comfort while online (Davis, 2002).

Internet Usage and loneliness (Amichai-Hamburger \& Ben-Artzi, 2003; Caplan, 2002; Kubey, Lavin, \& Barrows, 2001; Morahan-Martin \& Schumacher, 2003),Depression (Ybarra, Alexander, \& Mitchell, 2005; Young \& Rogers, 1998),Anxiety (Caplan, 2005a, 2005b; Spada et al., 2008; Yu-yuan, 2007), Shyness (Chak \& Leung, 2004; Roberts, Smith, \& Pollock, 2000Aggression (Kim, Namkoong, Ku, \& Kim, 2008),Introversion (Ebeling-Witte, Frank,\& Lester, 2007) Social Skill Deficits (Caplan, 2005a)

The cognitive behavioral model of Problematic Internet Use (Davis, 2001) suggests that individuals who suffer from psychosocial problems are more likely to develop Problematic Internet Use. 


\section{Teenage Technological Addictions (TTA) - Impact On Social Skills}

Internet addiction, also described as pathological internet use, is defined as an individual's inability to control his or her use of the internet, which eventually causes psychological, social, school and/or work difficulties in a person's life (Davis 2001; Young \& Rogers, 1998).

Problematic Internet use is multidimensional syndrome that consists of cognitive, emotional, and behavioral symptoms that result in difficulties with managing one's offline life (Caplan, 2002, 2003, 2005a, 2005b; Davis, 2001; Davis et al., 2002; Morahan-Martin \& Schumacher,2003).

Compulsive gambling (Mobilia, 1993), Overeating (Lesieur \& Blume, 1993), and Compulsive sexual behavior (Goodman, 1993). Computer dependency, excessive television viewing, obsessive video game playing (Keepers, 1991).

Literature suggests that symptoms of internet use includes maladaptive mood regulation, compulsive use of the Internet, a preference for online social interaction, cognitive preoccupation with the Internet, and negative outcomes due to Internet use (Caplan, 2005a, 2005b). LaRose, Lin,and Eastin (2003) argue that they involve in going online to alleviate negative moods, to relieve stress, loneliness, depression, or anxiety.

Using Internet to reduce negative emotional drives. Spada, Langston, Nikcevic, and Moneta (2008)

Internet usage is also becoming addiction as the other addictions like drugs, alcohol or gambling. This results in academic failure (Brady, 1996; Murphey, 1996); reduced work performance (Robert Half International, 1996), and even marital discord and separation (Quittner, 1997).

Although these findings, Less attention given to the relationships between internet addiction and Social Skills. Thus, the aim of this study is to identify the relationship between internet addiction and Social Skills.

\section{METHODOLOGY}

The data was collected from the areas closer to computer training institutions located in Hyderabad, Andhra Pradesh. Individuals were curious in research and during their break time assessments were conducted and later they were also provided refreshments. Before filling up the questionnaires no announcement about refreshments was done.

Total Sample consisted of 400 both Male and Female. 
Teenage Technological Addictions (TTA) - Impact On Social Skills

RESULTS:

\begin{tabular}{|l|c|c|c|}
\hline & TIME & PRIVACY & \multicolumn{1}{|c|}{ PRESSURE } \\
\hline BELOW 12 & $\checkmark$ & - & $\checkmark$ \\
\hline $13-20$ & $\checkmark$ & $\checkmark$ & $\checkmark$ \\
\hline $21-30$ & $\checkmark$ & - & $\checkmark$ \\
\hline $31-40$ & $\checkmark$ & $\checkmark$ & $\checkmark$ \\
\hline ABOVE 40 & $\checkmark$ & & $\checkmark$ \\
\hline
\end{tabular}

Demographic Variables with Percentage: Male Group

\begin{tabular}{|c|c|c|c|c|c|c|c|c|c|}
\hline Religion & Hindu (70\%) & $\begin{array}{l}\text { Muslim } \\
(20 \%)\end{array}$ & $\begin{array}{l}\text { Christian } \\
(10 \%)\end{array}$ & & & & & & \\
\hline Education & $\begin{array}{l}\text { Intermediate } \\
(20 \%)\end{array}$ & $\begin{array}{l}\text { Graduate } \\
(40 \%)\end{array}$ & $\begin{array}{l}\text { Post Graduate } \\
(15 \%)\end{array}$ & $\begin{array}{l}\text { Discontinued } \\
(25 \%)\end{array}$ & & & & & \\
\hline Occupation & $\begin{array}{l}\text { Student } \\
(58 \%)\end{array}$ & $\begin{array}{l}\text { Working } \\
(18 \%)\end{array}$ & $\begin{array}{ll}\text { Job } & \text { Hunt } \\
(12 \%) & \end{array}$ & $\begin{array}{l}\text { Discontinued } \\
\text { Job }(12 \%)\end{array}$ & & & & & \\
\hline $\begin{array}{l}\text { Marital } \\
\text { Status }\end{array}$ & $\begin{array}{l}\text { Married } \\
(10 \%)\end{array}$ & $\begin{array}{l}\text { Single } \\
(20 \%)\end{array}$ & $\begin{array}{l}\text { Living Separate } \\
(48 \%)\end{array}$ & Widow (1\%) & $\begin{array}{l}\text { Divorcee } \\
(21 \%)\end{array}$ & & & & \\
\hline $\begin{array}{l}\text { Family } \\
\text { Type }\end{array}$ & $\begin{array}{l}\text { Nuclear } \\
(27 \%)\end{array}$ & Joint (6\%) & $\begin{array}{l}\text { Living Separate } \\
(67 \%)\end{array}$ & & & & & & \\
\hline $\begin{array}{l}\text { Socio } \\
\text { Economic } \\
\text { Status }\end{array}$ & Low (20\%) & $\begin{array}{l}\text { Medium } \\
(50 \%)\end{array}$ & High (30\%) & & & & & & \\
\hline Internet Use & Career (12\%) & $\begin{array}{l}\text { Education } \\
(6 \%)\end{array}$ & $\begin{array}{l}\text { Entertainment } \\
(10 \%)\end{array}$ & Games (16\%) & $\begin{array}{l}\text { Mobile } \\
(20.5 \%)\end{array}$ & $\begin{array}{l}\text { Chatting } \\
(9 \%)\end{array}$ & $\begin{array}{l}\text { Information } \\
\text { Seeking } \\
(6 \%)\end{array}$ & $\begin{array}{l}\text { Porn } \\
(19.5 \%)\end{array}$ & $\begin{array}{l}\text { Any } \\
\text { Other } \\
(1 \%)\end{array}$ \\
\hline Hours Spent & $\begin{array}{ll}<1 & \text { Hour } \\
(16 \%) & \end{array}$ & $\begin{array}{l}\text { 1-3Hour } \\
(12 \%)\end{array}$ & $>3$ Hour $(62 \%)$ & $\begin{array}{l}\text { Always } \\
\text { Connected } \\
(10 \%)\end{array}$ & & & & & \\
\hline
\end{tabular}


Teenage Technological Addictions (TTA) - Impact On Social Skills

Demographic Variables with Percentage: Female Group

\begin{tabular}{|c|c|c|c|c|c|c|c|c|c|}
\hline Religion & Hindu (80\%) & $\begin{array}{l}\text { Muslim } \\
(15 \%)\end{array}$ & Christian (5\%) & & & & & & \\
\hline Education & $\begin{array}{l}\text { Intermediate } \\
(45 \%)\end{array}$ & $\begin{array}{l}\text { Graduate } \\
\text { (15\%) }\end{array}$ & $\begin{array}{l}\text { Post Graduate } \\
(10 \%)\end{array}$ & $\begin{array}{l}\text { Discontinued } \\
(30 \%)\end{array}$ & & & & & \\
\hline Occupation & $\begin{array}{l}\text { Student } \\
(50 \%)\end{array}$ & $\begin{array}{l}\text { Working } \\
(20 \%)\end{array}$ & $\begin{array}{ll}\text { Job } & \text { Hunt } \\
(152 \%) & \end{array}$ & $\begin{array}{l}\text { Discontinued } \\
\text { Job (15\%) }\end{array}$ & & & & & \\
\hline $\begin{array}{l}\text { Marital } \\
\text { Status }\end{array}$ & $\begin{array}{l}\text { Married } \\
(10 \%)\end{array}$ & $\begin{array}{l}\text { Single } \\
(12 \%)\end{array}$ & $\begin{array}{l}\text { Living } \\
\text { Separate (42\%) }\end{array}$ & Widow (6\%) & $\begin{array}{l}\text { Divorcee } \\
(30 \%)\end{array}$ & & & & \\
\hline $\begin{array}{l}\text { Family } \\
\text { Type }\end{array}$ & $\begin{array}{l}\text { Nuclear } \\
(29 \%)\end{array}$ & Joint (5\%) & $\begin{array}{l}\text { Living } \\
\text { Separate (66\%) }\end{array}$ & & & & & & \\
\hline $\begin{array}{l}\text { Socio } \\
\text { Economic } \\
\text { Status }\end{array}$ & Low (16\%) & $\begin{array}{l}\text { Medium } \\
(36 \%)\end{array}$ & High (48\%) & & & & & & \\
\hline Internet Use & Career (15\%) & $\begin{array}{l}\text { Education } \\
(2 \%)\end{array}$ & $\begin{array}{l}\text { Entertainment } \\
\text { (109) }\end{array}$ & Games (13\%) & $\begin{array}{l}\text { Mobile } \\
(13 \%)\end{array}$ & $\begin{array}{l}\text { Chatting } \\
(11 \%)\end{array}$ & $\begin{array}{l}\text { Information } \\
\text { Seeking } \\
(12 \%)\end{array}$ & $\begin{array}{l}\text { Porn } \\
(9 \%)\end{array}$ & $\begin{array}{l}\text { Any } \\
\text { Other } \\
(6 \%)\end{array}$ \\
\hline Hours Spent & $\begin{array}{lr}<\quad 1 & \text { Hour } \\
(17 \%) & \end{array}$ & $\begin{array}{l}\text { 1-3Hour } \\
(28 \%)\end{array}$ & $\begin{array}{l}>3 \text { Hour } \\
(45 \%)\end{array}$ & $\begin{array}{l}\text { Always } \\
\text { Connected } \\
(10 \%)\end{array}$ & & & & & \\
\hline
\end{tabular}

Internet Addiction Test Scores showed that the individuals who participated in this study were in the Moderate Addiction. experiencing occasional or frequent problems because of the Internet. You should consider their full impact on your life significantly high in the age group 21-30.

Social Skills: Scores depicted that the more loneliness/Social anxiety, conceit/ Haughtiness, Aggression/Antisocial behavior, Assertiveness/social Skills are in this sequential order in both the genders.

On Diagnostic Questionnaire the individuals scored more on Dependents. Addicted Internet users (Dependents) not many on the Normal Internet users (Non- Dependents). 
IMPAIRMENT: GENDER WISE

\begin{tabular}{|l|l|l|l|l|l|l|}
\hline \multicolumn{3}{|c|}{ Male } & \multicolumn{3}{c|}{ Female } \\
\hline Impairment & Mild & Moderate & Severe & Mild & Moderate & Sever E \\
\hline Academic & & & Severe & & Moderate & \\
\hline Relationship & & Moderate & & & Moderate & \\
\hline Financial & Mild & & & Mild & & \\
\hline Occupation & & Moderate & & Mild & & \\
\hline Physical & Mild & & & Mild & & \\
\hline
\end{tabular}

Pearson's Correlation Coefficient is -.3 indicating more the usage of internet leading to addiction lesser the social skills. As the Chi-Square Test value is higher than the table value. There is a significant relationship between Internet Usage and Social Skills.

\section{CONCLUSION}

The Increase of gifts preferred mostly smart phones, emotional blackmailing if not given any gift related to latest gadgets individuals feeling dejected. Aloof, Increased or decreased sexual appetite, Escaping from the society, compulsive responses, Losing time control internet, Decreased social interaction, Aggression towards family members, on Responsive to Cultural activities in family gatherings, Preoccupied with internet applications, Discussing only about technological updates, Unable to log out, Deceiving names, Decreased household chores, Technology preferred than Human beings, New relationships \& complicated ending with few months/years. Reason: chatting spending more time with computer partner, Still many more reason...Discussing personal /familial/professional/sexual/political issues with strangers, calling for danger, Urge to keep posted always with latest pictures of themselves/family/friends/pets/home many more. Committing mistakes not repenting later, No apologies, Feels ego hurt, Dejected if not accepted as friend in social network sites, Life without internet is empty, Boring, Joyless, Decreased appetite, Disturbed sleep, Late logins to find out what other friends/family is doing, Frequent interruptions while speaking to someone in person, Language usage change- exams, speaking short cut example: your-ur, Good Night -gn, following -flwg, Peer disturbed relations, Parental disturbances, Argumentative towards elders, Care \& Concern whenever felt, Opening door of danger- obscene pictures self/friends due to anger old issues unresolved etc., Depressed if someone does not accept as friend, Anxious what happened always about others life, Faulty statements about self/others to create problems, Cyber bullying, Cyber crime, Mailing stuff not really needed, Haphazard conversations, Wanting for more pen-pals, Going online when no one is at home, Using work Internet access for online 
activities not directly work related, Keeping Internet use a secret, Increased isolation, Overconfidence of being tech savvy, Lying to self and others, Ignoring guidelines, Searching ways to create many mail ID's with different names, Blaming others for need to internet use

Moderate addiction was found in the study if not taken care in the early stages might lead to severe addiction as other addiction treatment is suggested. Cognitive Behavior Therapy has shown better improvements for individuals who are addicted to internet Young, (1997)

Usage of internet appropriately is important rather than excess use of internet creating many impairments in the various aspects of life especially academics, relationships, financial, occupational and physical.

Findings of the previous research have correlated with this study indicating there is significant decrease in the social skills of individuals who are internet addicts.

\section{Source of Support: Nil}

Disclosure: No Conflict of Interest

\section{REFERENCES}

Amichai-Hamburger, Y., \& Ben-Artzi, E. (2003). Loneliness and internet use. Computers in Human Behavior, 19, 71-80

Brady, K. (April 21, 1996). Dropouts rise a net result of computers. The Buffalo Evening News,pg. 1.

Brenner V. (1997). Psychology of computer use: XLVLL parameters of internet use, abuse, and addiction: the first 90 days of the internet Usage Survey. Psychology Reports; 80:879-82

Caplan, S. E. (2002). Problematic internet use and psychosocial well-being: Development of a theory-based cognitive-behavioral measurement instrument. Computers in Human Behavior, 18(5), 553-575.

Caplan, S. E. (2002). Problematic internet use and psychosocial well-being: Development of a theory-based cognitive-behavioral measurement instrument. Computers in Human Behavior, 18(5), 553-575

Caplan, S. E. (2003). Preference for online social interaction: A theory of problematic internet use and psychosocial well-being. Communication Research, 30(6), 625-648.

Caplan, S. E. (2005a). A social skill account of problematic internet use. Journal of Communication, 55, 721-736.

Caplan, S. E. (2005b). Refining the cognitive behavioral model of problematic Internet use. Paper presented at the annual conference of the American Psychological Association, Washington, DC, August 2005.

Chak, K., \& Leung, L. (2004). Shyness and locus of control as predictors of internet addiction and Internet use. CyberPsychology \& Behavior, 7, 559-570. 
Chou C. (2001). internet heavy use and addiction among Taiwanese college students: an online interview. Cyber Psychology \& Behavior; 4:573-85.

Davis, R. A. (2001) A cognitive-behavioral model of pathological internet use. Computers in Human Behavior,17, 187-195

Davis, R. A. (2001). A cognitive-behavioral model of pathological internet use. Computers in Human Behavior, 17, 187-195.

Davis, R. A. (2001). A cognitive-behavioral model of pathological internet use.Computers in Human Behavior, 17, 187-195.

Davis, R. A., Flett, G. L., \& Besser, A. (2002). Validation of a new scale for measuring problematic internet use: Implications for pre-employment screening [Special issue: Internet and the workplace]. Cyber Psychology \& Behavior, 5, 331-345.

Davis, RA. , Flett, G L. \& Beser, A. (2002). Validation of a new scale for measuring problematic internet use. Cyber Psychology \& Behavior; 5:331-45.

Ebeling-Witte, S., Frank, M. L., \& Lester, D. (2007). Shyness, Internet use, and personality. CyberPsychology \& Behavior, 10, 713-716.

Goodman, A. (1993). Diagnosis and treatment of sexual addiction. Journal of Sex and Marital Therapy, 19, 225-251.

Greenfield, D.N. (2000). Psychological characteristics of compulsive internet use: a preliminary analysis. Cyber Psychology \& Behavior; 5:403-12.

Griffith,s M.D. Does internet and computer addiction exist? Some case study evidence. Cyber Psychology \& Behavior 2000; 3, 211-18.

Keepers, G. A. (1990). Pathological preoccupation with video games. Journal of the American Academy of Child and Adolescent Psychiatry, 29, 49-50.

Kim, E. J., Namkoong, K., Ku, T., \& Kim, S. J. (2008). The relationship between online game addiction and aggression, self-control and narcissistic personality traits.European Psychiatry, 23(3), 212-218.

Kubey, R. W., Lavin, M. J., \& Barrows, J. R. (2001). Internet use and collegiate academic performance decrements: Early findings. Journal of Communication,51, 366-382

LaRose, R., Lin, C. A., \& Eastin, M. S. (2003). Unregulated internet usage: Addiction, habit, or deficient self-regulation? Media Psychology, 5, 225-253

Lesieur, H. R., \& Blume, S. B. (1993). Pathological gambling, eating disorders, and the

Mobilia, P. (1993). Gambling as a rational addiction, Journal of Gambling Studies, 9(2), 121 151.

Morahan-Martin, J. \& Schumacher, P. (2000). incidence and correlates of pathological internet use among college students. Computers in Human Behavior; 16:13-295

Morahan-Martin, J., \& Schumacher, P. (2003). Loneliness and social uses of the internet. Computers in Human Behavior, 19, 659-671.

Murphey, B. (June, 1996). Computer addictions entangle students. The APA Monitor.

Mustafa Koç :Internet Addiction And Psychopatology: TOJET: The Turkish Online Journal of Educational Technology - January 2011, volume 10 Issue 1,143-148. 
Nie, N.H, Erbring L. (2000) internet and society. (Preliminary report). Stanford, CA: Stanford University,Stanford institute for the Quantitative Study of Society. www.stanford.edu/group/siqss/Press_Release/internetStudy.html (accessed May 18, 2008).

Quittner, J. (April 14, 1997). Divorce Internet style. Time, pg. 72

Robert Half International, Inc. (October 20, 1996). Misuse of the Internet may hamper productivity. Report from an internal study conducted by a private marketing research group.

Roberts, L. D., Smith, L. M., \& Pollock, C. M. (2000). 'U r a lot bolder on the net':Shyness and internet use. In W. R. Crozier (Ed.), Shyness: Development,consolidation and change (pp. 121-138). New York, NY: Routledge.

Shotton, M. (1991). The costs and benefits of "computer addiction." Behaviour and Information Technology, 10, 219-230.

Spada, M. M., Langston, B., Nikcevic, A. V., \& Moneta, G. B. (2008). The role of metacognitions in problematic internet use. Computers in Human Behavior, 24,23252335.

Spada, M. M., Langston, B., Nikcevic, A. V., \& Moneta, G. B. (2008). The role of metacognitions in problematic internet use. Computers in Human Behavior, 24,23252335.

Ybarra, M. L., Alexander, C., \& Mitchell, K. J. (2005). Depressive symptomatology, youth internet use, and online interactions: A national survey. Journal of Adolescent Health, 36, 9-18.

Young K. (1997) What makes the internet addictive: potential explanations for pathological internet use. Paper presented at the Annual Conference of The American Psychological Association, Chicago.

Young, K. S. \& Rogers, R. C. (1998) The relationship between depression and internet addiction. Cyber psychology and Behavior, 1, 25-28

Young, K. S. \& Rogers, R. C. (1998) The relationship between depression and internet addiction. Cyber psychology and Behavior, 1, 25-28.

Young, K. S. (1996). Caught in the net: how to recognize the signs of Internet addiction-and a winning strategy for recovery. New York: Wiley.

Young, K. S., \& Rogers, R. C. (1998). The relationship between depression and internet addiction. Cyber Psychology \& Behavior, 1, 25-28

Yu-yuan, L. (2007). Psycho-social related factors of junior high school students with internet addiction disorder. Chinese Journal of Clinical Psychology, 15, 422-423 